\title{
Response of temperate grasslands at different altitudes to simulated summer drought differed but scaled with annual precipitation
}

\author{
A. K. Gilgen ${ }^{1, *}$ and N. Buchmann ${ }^{1}$ \\ ${ }^{1}$ Institute of Plant Sciences, ETH Zurich, Zurich, Switzerland \\ * present address: Institute of Plant Sciences, University of Bern, Bern, Switzerland \\ Received: 17 April 2009 - Published in Biogeosciences Discuss.: 25 May 2009 \\ Revised: 21 October 2009 - Accepted: 21 October 2009 - Published: 9 November 2009
}

\begin{abstract}
Water is an important resource for plant life. Since climate scenarios for Switzerland predict an average reduction of $20 \%$ in summer precipitation until 2070 , understanding ecosystem responses to water shortage, e.g. in terms of plant productivity, is of major concern. Thus, we tested the effects of simulated summer drought on three managed grasslands along an altitudinal gradient in Switzerland from 2005 to 2007, representing typical management intensities at the respective altitude. We assessed the effects of experimental drought on above- and below-ground productivity, stand structure (LAI and vegetation height) and resource use (carbon and water). Responses of community above-ground productivity to reduced precipitation input differed among the three sites but scaled positively with total annual precipitation at the sites $\left(R^{2}=0.85\right)$. Annual community above-ground biomass productivity was significantly reduced by summer drought at the alpine site receiving the least amount of annual precipitation, while no significant decrease (rather an increase) was observed at the pre-alpine site receiving highest precipitation amounts in all three years. At the lowland site (intermediate precipitation sums), biomass productivity significantly decreased in response to drought only in the third year, after showing increased abundance of a drought tolerant weed species in the second year. No significant change in below-ground biomass productivity was observed at any of the sites in response to simulated summer drought. However, vegetation carbon isotope ratios increased under drought conditions, indicating an increase in water use efficiency. We conclude that there is no general drought response of Swiss grasslands, but that sites with lower annual precipitation seem to be more vulnerable to summer drought
\end{abstract}

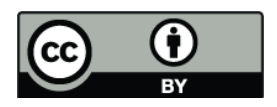

Correspondence to: A. K. Gilgen (anna.gilgen@ips.unibe.ch) than sites with higher annual precipitation, and thus sitespecific adaptation of management strategies will be needed, especially in regions with low annual precipitation.

\section{Introduction}

Water availability is among the strongest limitations to plant productivity globally, even in temperate or boreal regions (Lambers et al., 1998). Annual above-ground productivity of vegetation strongly depends on mean annual precipitation (for grassland: Paruelo et al., 1999; Knapp and Smith, 2001). Water stress for plants can arise from low precipitation inputs, high rates of water loss due to high atmospheric vapour pressure deficit (VPD) or from drying soil, all mechanisms ultimately reducing plant productivity. Such effects might become more pronounced since water stress is predicted to increase in the future in certain regions due to climate change, e.g. in Central Europe, for which decreasing summer precipitation is expected (Christensen et al., 2007). Projections for Switzerland indicate that by 2070 the mean decrease of summer precipitation (June through August) might be around $20 \%$ compared to 1990 with a maximum decrease of $40 \%$ (Frei et al., 2006). Thus, we expect ecosystem processes, from microbial activities to plant performance, to be strongly affected. At the same time, the response to drought of terrestrial ecosystems might vary dependent on vegetation composition and local environmental conditions.

While research on drought effects on grassland species has often been carried out under controlled conditions (e.g. Arp et al., 1998; Karsten and MacAdam, 2001), research at the ecosystem level in the field used two approaches: (1) naturally occurring droughts and their impact on the long-term field trials (Weaver et al., 1935; Gibbens and Beck, 1988;

Published by Copernicus Publications on behalf of the European Geosciences Union. 
Table 1. Description of the three experimental grassland sites in Switzerland.

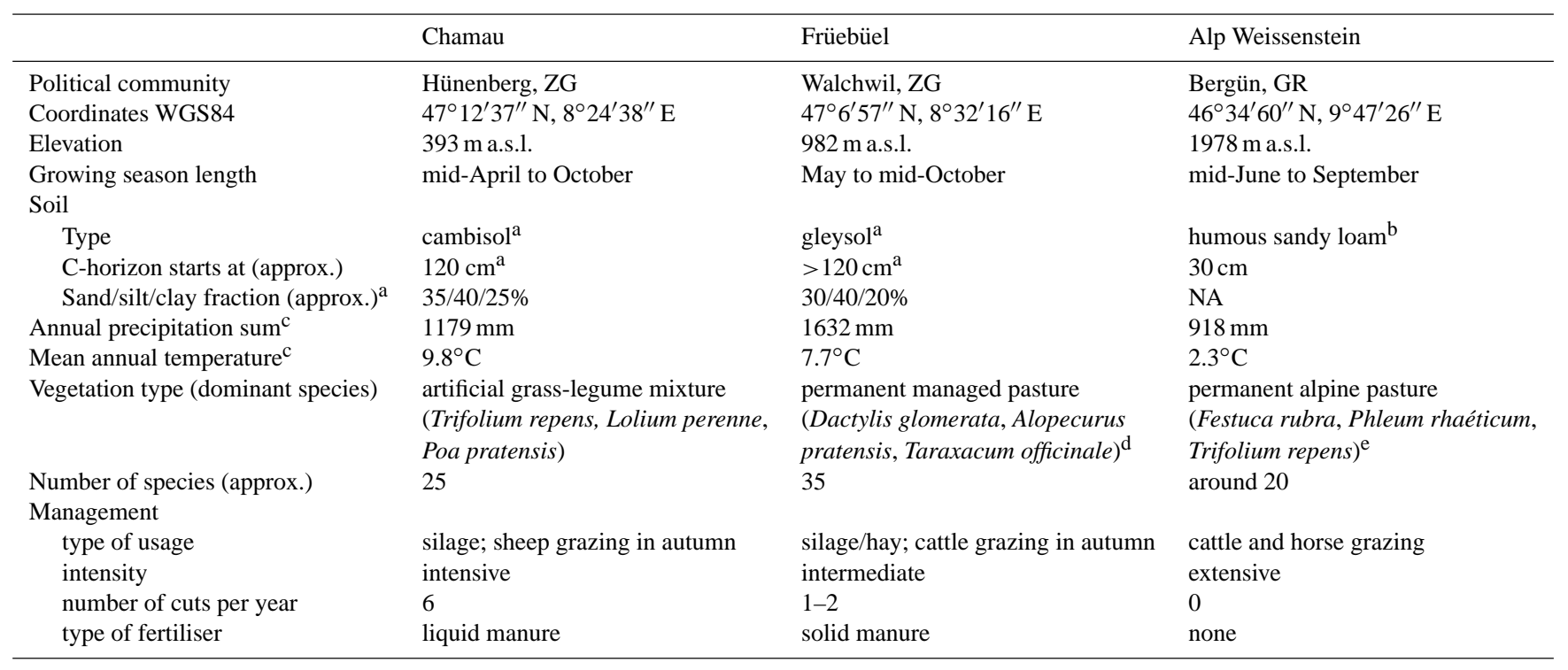

a Roth (2006)

b Schärer (2003)

c data from Zeeman (2008) adapted with data from MeteoSwiss

d Sautier (2007)

e Keller (2006)

Bollinger et al., 1991; Stampfli and Zeiter, 2004) and (2) field experiments manipulating rainfall amounts. Such manipulation studies have been carried out in arid or semi-arid regions where drought is occurring frequently (e.g. Sternberg et al., 1999; Greco and Cavagnaro, 2003; Köchy and Wilson, 2004; English et al., 2005; Schwinning et al., 2005; HeislerWhite et al., 2008; Sherry et al., 2008) but also in temperate grasslands where drought is not a severe problem today (e.g. Grime et al., 2000; Morecroft et al., 2004; Kahmen et al., 2005; Mikkelsen et al., 2008). A number of studies focused on the effects of changes in precipitation timing and amounts on $\mathrm{C}_{4}$ dominated grasslands (e.g. Knapp et al., 2001; Fay et al., 2002, 2003; Nippert et al., 2009). In most of these manipulation studies, productivity of common grassland species was greatly reduced, carbon (C) allocation to below-ground parts increased and deep rooted species were more drought resistant, supporting studies carried out with single species under controlled conditions. However, detailed information on the drought response of $\mathrm{C}_{3}$ dominated temperate grasslands in Europe is still rare.

This study therefore aimed to assess the responses to simulated extreme summer drought of three temperate grasslands at different altitudes in Switzerland. We excluded precipitation with transparent rain shelters and focused on the following questions: (1) How does community above-ground biomass productivity of these three grasslands respond to simulated summer drought? (2) Is community below-ground biomass productivity affected by simulated summer drought as well? (3) Do different plant functional types differ in their response to the drought treatment? We hypothesised that (1) the simulated summer drought decreases community aboveground productivity because water is one of the key resources for plant growth, (2) root biomass productivity increases with drought because of increased foraging for water, (3) different plant functional types differ in their response to simulated summer drought due to their different rooting patterns.

\section{Materials and methods}

\subsection{Experimental sites and setup}

The study was conducted at three different temperate grassland sites across Switzerland, representing Swiss grassland systems at the respective altitudes (Table 1). The experiment was established by the end of June 2005 at the two lower sites, Chamau and Früebüel, and in July 2006 at the alpine site, Alp Weissenstein, and was continued until 2007, thus during three and two growing seasons, respectively. At each site, we installed five portable rain shelters and excluded rainfall in spring/summer to simulate a pronounced drought. In 2006, two additional rain shelters and control plots were installed at Chamau and one each at Früebüel. The tunnelshaped rain shelters had an area of $3 \times 3.5 \mathrm{~m}$ and were about $2.1 \mathrm{~m}$ high at the highest point. During the entire drought 
Table 2. Dates of rain exclusion period and amounts of precipitation excluded during the three years of experiment and average long-term annual precipitation sum at all sites. The fraction of annual precipitation is given in brackets.

\begin{tabular}{llllllll}
\hline & \multicolumn{2}{c}{2005} & & 2006 & & 2007 \\
& $\begin{array}{l}\text { Treatment } \\
\text { period }\end{array}$ & $\begin{array}{l}\text { Amount } \\
{[\mathrm{mm}]}\end{array}$ & $\begin{array}{l}\text { Treatment } \\
\text { period }\end{array}$ & $\begin{array}{l}\text { Amount } \\
{[\mathrm{mm}]}\end{array}$ & $\begin{array}{l}\text { Treatment } \\
\text { period }\end{array}$ & $\begin{array}{l}\text { Amount } \\
{[\mathrm{mm}]}\end{array}$ & $\begin{array}{l}\text { Annual } \\
\text { precipitation } \\
{[\mathrm{mm}]^{\mathrm{a}}}\end{array}$ \\
\hline Chamau & 24 June-19 Sep & 491(42\%) & 31 May-17 Aug & 271(24\%) & 2 May-10 July & $403(33 \%)$ & 1159 \\
Früebüel & 23 June-19 Sep & $763(52 \%)$ & 31 May-17 Aug & $388(24 \%)$ & 7 May-20 July & $589(33 \%)$ & 1534 \\
Alp Weissenstein & - & - & 6 July-24 Aug & 248 (29\%) & 20 June-23 Aug & $311(32 \%)$ & 975 \\
\hline
\end{tabular}

a data from MeteoSwiss stations Cham (1972-2000, for Chamau), Zugerberg (1972-2008, for Früebüel) and Preda (1961-1974, for Alp Weissenstein)

treatment period, the steel frames were covered with transparent plastic foils $(200 \mu \mathrm{m}$; Gewächshausfolie UV 5, folitec Agrarfolien-Vertriebs $\mathrm{GmbH}$, Westerburg, Germany). To ensure sufficient air circulation, the rain shelters were not closed down to the ground and the main opening of the shelters was oriented towards the main wind direction. Based on regional climate model projections (e.g. Frei et al., 2006), we determined that reducing May to August precipitation by $45 \%$ compared to today would simulate an extreme summer drought in the future. A period of eight to ten weeks beginning in May at Chamau and Früebüel and six to eight weeks at Alp Weissenstein was required to achieve this target reduction. Due to the very variable weather conditions, the amounts of precipitation excluded varied over the three years of treatment but relative amounts at the three sites were comparable within years (Table 2). We established a core area of $1 \times 2 \mathrm{~m}$ in the middle of the rain shelters to exclude any direct rain input on plots. All rainfall removed by the shelters was lead away from the respective plots. Control plots (equal number of replicates as for the shelters) located next to the sheltered plots received natural rainfall amounts. The same plots were used throughout the three years of the experiment. During the three years of the experiment, no fertiliser was applied to the plots and no grazing was allowed on the plots. In autumn 2006, the weed species Rumex obtusifolius L. had to be removed manually from the experimental plots at Chamau due to Swiss regulations (Gilgen et al., 2010), overseeding took place in early March 2007 to re-establish a closed vegetation cover.

\subsection{Micrometeorological measurements}

Microclimatic variables were continuously monitored close to the centre of two drought and control plots per site, starting in autumn 2005 at Früebüel, spring 2006 at Chamau and summer 2006 at Alp Weissenstein. Soil temperature (Precision IC Temperature Transducer AD592AN, Analog Devices, Norwood, MA, USA), soil moisture at three soil depth $\left(5,15\right.$ and $30 \mathrm{~cm}$ ) using $20 \mathrm{~cm}$ long $\mathrm{ECH}_{2} \mathrm{O}$ probes (EC-
20, Decagon Devices, Inc., Pullman, WA, USA) and soil heat flux (HFP01, Hukseflux Thermal Sensors B.V., Delft, Netherlands) close to the soil surface were recorded. We also monitored air temperature at 60 and $160 \mathrm{~cm}$ (using the same sensors as for soil temperature but with ventilation) and photosynthetically active radiation (PAR LITE, Kipp \& Zonen B.V., Delft, Netherlands). The air temperature sensors were disconnected in winter and spring 2006/2007 due to technical modifications in the setup. After mid-October 2007, the air temperature sensors were not ventilated any longer to save battery lifetime. Measurements were made every $10 \mathrm{~s}$ while ten minute averages were logged with a CR10X data logger (Campbell Scientific Inc., Logan, UT, USA).

In addition, we assessed soil moisture by taking additional measurements of gravimetric soil water content in 2007 . We therefore sampled $15 \mathrm{~cm}$ deep soil cores from the centre of the plots and divided them into three $5 \mathrm{~cm}$ pieces. Samples were stored in tightly sealed plastic bags and fresh weight was measured immediately after returning from the field. The soil cores were dried to weight constancy at $100^{\circ} \mathrm{C}$ (some days) and dry weight was measured afterwards. Gravimetric soil water content was then calculated as the difference of the fresh and the dry weight (weight of the water) divided by the dry weight (weight of the soil).

\subsection{Above-ground productivity}

Above-ground biomass was harvested at the cutting dates of the surrounding farm, i.e. six times per year at Chamau (three times in 2005), two times per year at Früebüel (once in 2005) and once at the end of the growing season (end of September) at Alp Weissenstein. Biomass was collected using $20 \times 50 \mathrm{~cm}$ frames that were randomly placed on the plots in 2005 and installed at fixed locations starting spring 2006. Cutting height of the vegetation was approximately $7 \mathrm{~cm}$ above the soil according to the common management practice on the farms. Two samples per plot were taken and then pooled for the analyses (representing $0.2 \mathrm{~m}^{2}$ ). Biomass was stored in plastic bags at $4^{\circ} \mathrm{C}$ for a maximum of one week 
until it could be separated into species (plant functional types for Alp Weissenstein) and dried at $60^{\circ} \mathrm{C}$ until weight constancy. Dry matter was then determined for each species sample, and the sum of all samples from the same plots was used as an estimate for community above-ground biomass productivity. Each species was assigned a plant functional type (grass, forb (i.e. non-leguminous forb) or legume). The dead biomass (often also referred to as necromass) was considered its own plant functional type and was never separated into species (i.e. biomass of the other three functional types was alive by definition). It was however included in community above-ground productivity estimates (often also called phytomass).

\subsection{LAI and vegetation height}

During the growing seasons 2006 and 2007 (only 2007 at Alp Weissenstein), leaf area index (LAI) was measured approximately $7 \mathrm{~cm}$ above soil (cutting height) using an LAI-2000 Plant Canopy Analyzer (LI-COR Biosciences, Lincoln, NE, USA). Five measurements distributed over the plot were averaged to represent the plot LAI. A $270^{\circ}$ view cap was used to reduce plots size required for measurements, i.e. only $90^{\circ}$ of the sensor view were used for measurements. Vegetation height was estimated at the same dates as LAI using a stick and a falling styrofoam plate $(0.5 \times 0.5 \mathrm{~m}, 1 \mathrm{~cm}$ thick $)$. Two to four measurements were averaged for each plot.

\subsection{Root biomass productivity}

Root biomass productivity at the community level over the complete growing season was determined at Chamau and Früebüel in 2007 and over nearly two growing seasons (2006 and 2007) at Alp Weissenstein using ingrowth cores $(4.4 \mathrm{~cm}$ diameter, $30 \mathrm{~cm}$ length). Cores were positioned in an angle of approximately $45^{\circ}$. All ingrowth cores were filled with root-free, sieved ( $2 \mathrm{~mm}$ ) soil from the corresponding site. Ingrowth cores were installed from 13 March 2007 to 1 December 2007 at Chamau (263 days), from 15 December 2006 to 1 December 2007 at Früebüel (351 days), and from 14 July 2006 to 25 September 2007 at Alp Weissenstein (438 days). One ingrowth core per plot was buried at Alp Weissenstein while two cores per plot were used at the two other sites. After removal from the soil, cores were stored at $4^{\circ} \mathrm{C}$ until further analysis. The ingrown roots were washed from the soil cores in the laboratory, roots were dried to weight constancy at $60^{\circ} \mathrm{C}$ and the dry weight was determined. Where two ingrowth cores had been installed and recovered, root biomass of two cores was pooled to calculate root productivity of the plot. In some cases, part of the soil was lost when removing the ingrowth cores from the soil. Therefore, the actual length of the soil core was used to calculate the amount of roots per unit soil depth. As the ingrowth cores remained in the field for different time periods at the three sites, the root weight was divided by the number of days that roots had been al- lowed to grow into the cores and then multiplied by 365 to represent the root mass per $\mathrm{m}^{2}$ and year.

\subsection{Carbon isotope and nitrogen concentration measurements}

To determine carbon isotope ratios $\left(\delta^{13} \mathrm{C}\right)$ and nitrogen concentrations, the most abundant species were sampled at Chamau (Agrostis stolonifera L., Alopecurus pratensis L., Dactylis glomerata L., Lolium multiflorum LAM., Phleum pratense L. AGG., Poa pratensis L. AGG., Poa trivialis L. S.L., Rumex obtusifolius L., and Trifolium repens L.) and Früebüel (Agrostis capillaris L., A. stolonifera, A. pratensis, Anthoxanthum odoratum L., P. pratense, P. pratensis, P. trivialis, Rumex acetosa L., R. obtusifolius, and T. repens), while the four plant functional types were analysed at Alp Weissenstein. Biomass was ground to a fine powder and analysed using a Flash EA 1112 Series elemental analyser (Thermo Italy, former CE Instruments, Rhodano, Italy) coupled to a Finnigan MAT Delta ${ }^{\text {plus }} \mathrm{XP}$ isotope ratio mass spectrometer (Finnigan MAT, Bremen, Germany) via a 6-port valve (Brooks et al., 2003), a ConFlo III (Werner et al., 1999) and an additional Nafion-trap backed by a conventional $\mathrm{Mg}\left(\mathrm{ClO}_{4}\right)_{2}$-trap followed by a 4-port valve (Werner, 2003) between reduction tube and GC column. Post-run offline calculations (blank, offset and possibly drift corrections) were performed to assign the final $\delta$-values on the V-PDB and AIR- $\mathrm{N}_{2}$ scales according to Werner and Brand (2001). The long-time precision for the lab's quality control standard tyrosine ( $\sim 2.5$ years) was $0.05 \%$ o for $\delta^{13} \mathrm{C}$. Precision for $\mathrm{N}$ concentrations was $0.05 \%$. For statistical analyses, isotope and nitrogen data were weighted by biomass to calculate a vegetation and functional group mean for each plot.

\subsection{Statistical analysis}

Due to the rather small number of replicates $(n=5-7)$, all plots were included in the statistical analyses of biomass, vegetation height, $\delta^{13} \mathrm{C}$ and $\mathrm{N}$ concentrations, i.e. no outliers were excluded. LAI values were excluded only if the standard error of the five measurements per plot was higher than a third of the mean LAI of the plot or if MTA (mean tilt angle) was below $30 \%$ (criteria used for 2007 since this information was not available for 2006).

Statistical analyses were performed using R 2.5.0 (R Development Core Team, 2007). Community above-ground and functional type biomass, LAI, vegetation height and isotope signatures were generally all analysed with the same ANOVA model. In a first step, the full datasets were analysed (all sites over all years), using an ANOVA model considering site, harvest date, treatment (control vs. drought treatment) and all interactions, including the triple interaction. In a second step, datasets were analysed for each year separately using the same model. In a third step, the dataset was analysed for each site separately and finally for each harvest 


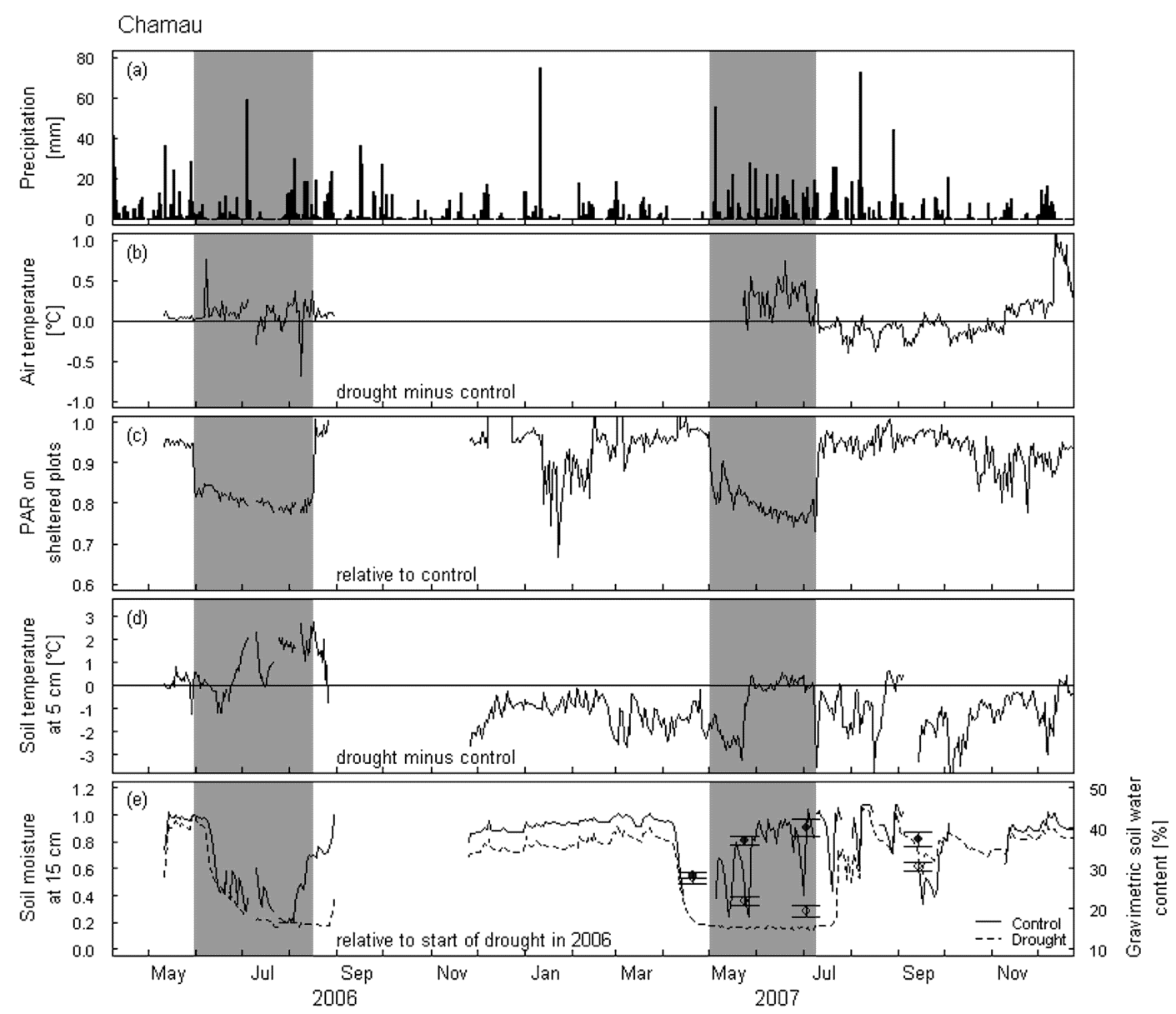

Fig. 1. Micrometeorology during the experiment at Chamau: daily precipitation sum (a), difference of daily average air temperature at $160 \mathrm{~cm}$ between drought and control plots (b), proportion of total photosynthetically active radiation (PAR) relative to the control plots (c), difference of daily average soil temperature at $5 \mathrm{~cm}$ depth between drought and control plots (d), and relative development of soil moisture at $15 \mathrm{~cm}$ depth (relative to the soil moisture at the beginning of the drought treatment in 2006; e). Solid lines: control plots, dashed lines: drought plots. Measurements of gravimetric soil water content in soil cores from 10-15 cm are given as points (open symbols for drought plots). The periods of drought treatment are shaded in grey. Averages of two plots per treatment are shown.

date separately. The model structure remained the same but the terms site and then also harvest date were removed. Root biomass data were analysed using an ANOVA model testing site, treatment and their interaction.

\section{Results}

\subsection{Micrometeorological measurements}

Annual precipitation sums were quite similar in 2005 $(1170 \mathrm{~mm}$ and $1481 \mathrm{~mm}$ at Chamau and Früebüel, respectively) and $2006(1136 \mathrm{~mm}, 1649 \mathrm{~mm}$ and $867 \mathrm{~mm}$ at Chamau, Früebüel and Alp Weissenstein, respectively), but around $100 \mathrm{~mm}$ higher at all three sites in $2007(1232 \mathrm{~mm}$, $1765 \mathrm{~mm}$ and $969 \mathrm{~mm}$ at Chamau, Früebüel and Alp Weissenstein, respectively, Zeeman et al., 2009, adjusted with data from nearby MeteoSwiss stations). While in 2006, July was naturally dry, spring 2007 started with very low precipitation but was followed by a rather wet summer 2007 (Fig. 1a).

The rain shelters had no substantial effect on daily average and minimum air temperatures at $160 \mathrm{~cm}$ height (shown for Chamau; Fig. 1b): at Chamau, the average temperature change during the drought treatment was $-0.03^{\circ} \mathrm{C}$, at Früebüel $0.2^{\circ} \mathrm{C}$ and at Alp Weissenstein $0.1^{\circ} \mathrm{C}$. The rain shelters increased daily maximum temperatures at Chamau and Früebüel (by around $0.8^{\circ} \mathrm{C}$ ) while no effect was seen at Alp Weissenstein. The plastic foils reduced average daily PAR sums by $20 \%$ at Chamau and Früebüel and by $26 \%$ at Alp Weissenstein (Fig. 1c). The effect of the shelters on soil temperature was also small: in general, there was an increase of less than $1{ }^{\circ} \mathrm{C}$ (but a decrease of $0.3^{\circ} \mathrm{C}$ at Alp Weissenstein) in soil temperature under the shelters compared to unsheltered periods (Fig. 1d). However, the rain shelters had the 
Table 3. Effect of drought on community (i.e. sum of dead and alive), alive and dead annual above-ground biomass productivity at Chamau (including Rumex obtusifolius), Früebüel and Alp Weissenstein in $\mathrm{g} \mathrm{m}^{-2}$. Means and standard errors are given ( $\left.n=5-6\right)$. Significantly different means $(P \leq 0.05)$ are given in bold, marginally significant differences $(0.1 \geq P>0.05)$ in italics.

\begin{tabular}{rccccccccc}
\hline & \multicolumn{3}{c}{ Chamau } & \multicolumn{3}{c}{ Früiebüel } & & \multicolumn{2}{c}{ Alp Weissenstein } \\
\hline & control & drought & $P$ & control & drought & $P$ & control & drought & $P$ \\
\hline $2005^{\text {a }}$ & & & & & & & & & \\
community & $477 \pm 53$ & $425 \pm 60$ & 0.6 & $248 \pm 40$ & $260 \pm 53$ & 0.9 & - & - & - \\
alive & $457 \pm 55$ & $398 \pm 60$ & 0.5 & $220 \pm 35$ & $235 \pm 49$ & 0.8 & - & - & - \\
dead & $20 \pm 4$ & $26 \pm 5$ & 0.3 & $28 \pm 6$ & $26 \pm 4$ & 0.7 & - & - & - \\
$2006 \quad$ & & & & & & & & & \\
community & $931 \pm 174$ & $895 \pm 185$ & 0.2 & $590 \pm 77$ & $607 \pm 69$ & 0.9 & $\mathbf{2 8 4} \pm \mathbf{9}$ & $\mathbf{1 8 4} \pm \mathbf{2 6}$ & $\mathbf{0 . 0 0 7}$ \\
alive & $909 \pm 173$ & $862 \pm 181$ & 0.9 & $535 \pm 76$ & $531 \pm 61$ & 1.0 & $\mathbf{1 8 0} \pm \mathbf{1 1}$ & $\mathbf{5 5} \pm \mathbf{7}$ & $<\mathbf{0 . 0 0 1}$ \\
dead & $22 \pm 2$ & $33 \pm 4$ & 0.05 & $55 \pm 6$ & $76 \pm 12$ & 0.1 & $104 \pm 2$ & $128 \pm 24$ & 0.3 \\
$2007 \quad$ & & & & & & & & & \\
community & $1211 \pm 134$ & $887 \pm 56$ & 0.06 & $616 \pm 77$ & $676 \pm 57$ & 0.5 & $\mathbf{4 8 7} \pm \mathbf{3 0}$ & $\mathbf{3 3 8} \pm \mathbf{4 5}$ & $\mathbf{0 . 0 2}$ \\
alive & $\mathbf{1 1 6 0} \pm \mathbf{1 3 0}$ & $\mathbf{8 2 0} \pm \mathbf{5 2}$ & $\mathbf{0 . 0 4}$ & $416 \pm 64$ & $477 \pm 30$ & 0.4 & $191 \pm 34$ & $119 \pm 28$ & 0.1 \\
dead & $52 \pm 6$ & $67 \pm 6$ & 0.08 & $200 \pm 25$ & $199 \pm 38$ & 1.0 & $296 \pm 23$ & $218 \pm 29$ & 0.07 \\
\hline
\end{tabular}

a Annual biomass productivity sum based on only three (instead of six) and one (instead of two) harvests at Chamau and Früebüel, respectively.

desired effect on soil moisture. Maximum reduction of soil moisture was around $83 \%$ at Chamau, with soil moisture being reduced by 20 to $60 \%$ during the drought treatment. Additional measurements of gravimetric soil water content showed a similar pattern as the continuous measurements (Fig. 1e). Due to lack of rain in the weeks prior to the start of the treatment, soil moisture dropped to very low levels in both, drought and control plots before the start of the drought treatment in 2007. At Früebuiel, the effect of the shelters on soil moisture was smaller than at Chamau because the site was generally much wetter: soil moisture was reduced on average by $30 \%$ at $30 \mathrm{~cm}$ soil depth during the drought treatment. At Alp Weissenstein, no data from continuous measurements were available due to technical problems, but drought significantly reduced gravimetric soil water content in $0-5 \mathrm{~cm}$ depth at the end of the drought treatment (absolute reduction of $41 \%, P<0.001)$.

\subsection{Above-ground productivity}

Overall, annual community above-ground biomass differed significantly among the three sites $(P<0.001)$. At Chamau, annual community above-ground productivities were similar in 2005 and 2006 for both treatments but drought tended to decrease community above-ground productivity in 2007 . No treatment effect was found at Früebuiel in any of the three years, while annual community above-ground productivity at Alp Weissenstein was significantly decreased by drought in both years (Table 3). However, above-ground productivities at Chamau were strongly influenced by one weed species, Rumex obtusifolius, which gained competitive advantage over the other species in 2006 (Gilgen et al., 2010). We therefore excluded $R$. obtusifolius biomass at Chamau from all further above-ground productivity analyses. As a result, the overall drought effect across all sites and all three years became significant $(P=0.02$ when including year in the analysis, data not shown). We found a strong relationship of the average annual community above-ground biomass response with annual precipitation sum $\left(R^{2}=0.73, P=0.004\right.$; without Rumex: $R^{2}=0.85, P<0.001$; Fig. $2 \mathrm{a}$ ), which was much stronger than the relationship with amount of precipitation excluded $\left(R^{2}=0.33, P=0.08\right.$; without Rumex: $R^{2}=0.60$, $P=0.01$; Fig. 2b). No such relationship was found when relating above-ground biomass response to the fraction of annual precipitation excluded by the shelters $\left(R^{2}<0.001\right.$, $P=0.89)$ or to growing degree days $\left(R^{2}<0.001, P=0.5\right)$.

Drought also affected vegetation composition and species richness. At Chamau, the average number of species was only slightly affected in the first two years (2005 and 2006), but significantly reduced by drought from 7.3 to 5.3 in 2007 . At Alp Weissenstein, the average species number was significantly reduced in 2006 but not in 2007, while at Früebüel, no significant impact on species richness was found (data not shown). Focusing on the drought responses of the four plant functional types (PFT) separately (Table 4, upper part) revealed significant differences among sites (except for forbs that grew similar amounts of biomass at all sites) but only slight differences of annual PFT above-ground productivities between treatments. Thus, over the three-year experiment, site was the most important factor influencing annual aboveground biomass productivities of the community as well as of individual PFTs. In comparison, impacts of the drought treatment significantly only affected the annual amount of dead biomass in $2006(P=0.05)$ and grass biomass in 2007 $(P=0.03)$, while annual above-ground productivities of forbs 
and legumes were not significantly affected in any of the three years.

Community above-ground regrowth (i.e. biomass grown between cutting dates) across all sites and all three years of the experiment (Fig. 3, Table 4, lower part) was affected by site and harvest date $(P<0.001)$ as well as by the drought treatment $(P=0.003)$. A significant site $\times$ treatment interaction $(P=0.001)$ indicated differing grassland responses to drought at the three sites, as already observed for the annual community above-ground productivities. Including year in the analysis did not change significance levels and was thus omitted. When analysing the three years separately, site and harvest date explained a large fraction of the variation in productivity in all three years (2005-2007), while the treatment effect was insignificant in 2005, it became marginally significant in $2006(P=0.06)$ and stayed significant in 2007 $(P=0.01)$. In 2007, the drought treatment showed highly significant effects on above-ground productivities at Chamau $(P=0.001)$ and Alp Weissenstein $(P<0.001)$, but still no effects at Früebüel $(P=0.5$; Fig. 3$)$. These annual patterns could also be seen in the response of the single harvests that were unaffected by the drought treatment at Früebüel and in the two first years at Chamau (except for the fifth harvest in 2006), but significantly reduced at Chamau in the third year (first, third and fourth harvest) and also strongly reduced at Alp Weissenstein (Fig. 3). The date $\times$ treatment interaction term was never significant, indicating that the direction of the drought responses of the respective grasslands was stable over time (Table 4, lower part).

Focusing on the different PFTs clearly showed that grasses resembled the drought response of the community aboveground productivity best (independent of Rumex). The drought treatment clearly decreased grass regrowth aboveground $(P=0.001)$. Although this response differed among sites (drought strongly decreased grass productivities at Chamau and Alp Weissenstein but no effect was observed at Früebüel; site $\times$ treatment interaction: $P<0.001$ ), the response of grasses to drought was stable over the growing season (harvest date $\times$ treatment interaction: not significant). Furthermore, similar patterns for community and grass above-ground productivity were also found when analysing the years separately (except site effect in 2005): grass productivity differed among the three sites and grass regrowth changed during the growing season (site and harvest date effects: $P<0.001)$. Forbs reacted to drought with decreased regrowth (overall: $P=0.007$ ), particularly in 2006. Unlike their annual productivities, forb regrowth differed between sites and also during the season (site and harvest date effects: $P<0.001$ ), but the direction of the drought response was unaffected by site and harvest date (overall site $\times$ treatment and harvest date $\times$ treatment interactions: $P>0.6$ ). Furthermore, legumes were generally positively affected by the drought treatment (overall: $P=0.005$ ), particularly in the year 2007, but this was driven by the positive drought response at Chamau (data not shown).

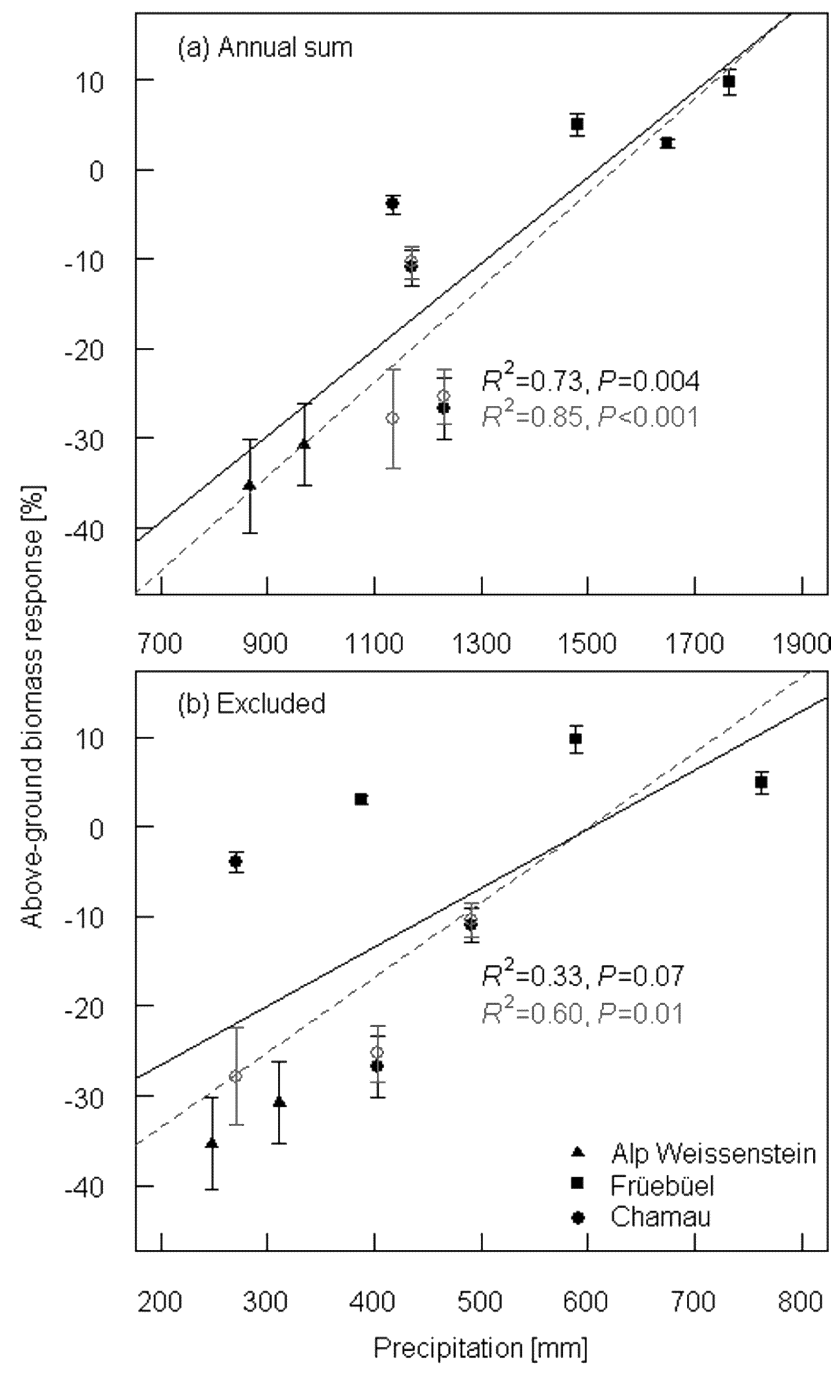

Fig. 2. Relationships of annual precipitation sums (a) and of excluded amounts of precipitation (b) with the average change in annual community above-ground biomass productivities in response to the drought treatment. $R^{2}$ and $P$ values for the regression of annual above-ground biomass excluding Rumex obtusifolius at Chamau are given in grey (open symbols, dashed line).

\subsection{LAI and vegetation height}

LAI measurements during 2006 and 2007 (Fig. 4) represented above-ground biomass regrowth patterns in higher temporal resolution than community above-ground productivity and varied significantly during the growing seasons $(P<0.001)$. Similar to productivity measurements, no significant drought effect on LAI was found at Chamau in 2006 (except very early in the season), probably confounded by Rumex abundance. In contrast, the drought response of LAI in 2007 was stronger than that of above-ground productivity, with drought lowering LAI values significantly $(P<0.001)$. At Früebüel, LAI was negatively affected by drought in 
Table 4. Results of the ANOVA models for annual sums of above-ground biomass and above-ground harvest yields of community (comm.=sum of dead and alive biomass) and plant functional type (grass, forb (excluding Rumex obtusifolius at Chamau), legume; only alive biomass) as well as dead above-ground biomass. Main factors are site (Chamau, Früebüel or Alp Weissenstein), harvest date and treatment (drought vs. control). Significant $P$ values $(P \leq 0.05)$ are given in bold, marginally significant values $(0.1 \geq P>0.05)$ in italics; $n=5-6$.

\begin{tabular}{|c|c|c|c|c|c|c|c|c|c|c|c|c|c|c|c|c|c|c|c|c|}
\hline & \multicolumn{5}{|c|}{ All years } & \multicolumn{5}{|c|}{2005} & \multicolumn{5}{|c|}{2006} & \multicolumn{5}{|c|}{2007} \\
\hline & Comm. & Grass & Forb & Leg. & Dead & Comm. & Grass & Forb & Leg. & Dead & Comm. & Grass & Forb & Leg. & Dead & Comm. & Grass & Forb & Leg. & Dead \\
\hline \multicolumn{21}{|c|}{ Annual above-ground biomass sums } \\
\hline Site & $<0.001$ & $<0.001$ & 0.2 & $<0.001$ & $<0.001$ & 0.002 & $<0.001$ & 0.01 & 0.07 & 0.4 & $<0.001$ & $<0.001$ & 0.3 & $<0.001$ & $<0.001$ & $<0.001$ & $<0.001$ & 0.2 & 0.006 & $<0.001$ \\
\hline Treatment & 0.1 & 0.08 & 0.06 & 0.2 & 1.0 & 0.7 & 0.7 & 0.3 & 0.2 & 0.7 & 0.1 & 0.2 & 0.1 & 1.0 & 0.05 & 0.05 & 0.03 & 0.6 & 0.2 & 0.4 \\
\hline Site $\times$ Treatment & 0.2 & 0.05 & 0.7 & 0.1 & 0.6 & 0.6 & 0.1 & 0.2 & 0.04 & 0.4 & 0.3 & 0.4 & 0.7 & 0.9 & 0.8 & 0.05 & 0.004 & 0.4 & 0.2 & 0.2 \\
\hline \multicolumn{21}{|c|}{ Above-ground harvest yields } \\
\hline Site & $<0.001$ & $<0.001$ & $<0.001$ & $<0.001$ & $<0.001$ & 0.02 & 0.5 & $<0.001$ & 0.7 & $<0.001$ & $<0.001$ & $<0.001$ & $<0.001$ & 0.003 & $<0.001$ & $<0.001$ & $<0.001$ & $<0.001$ & 0.002 & $<0.001$ \\
\hline Harvest date & $<0.001$ & $<0.001$ & $<0.001$ & 0.05 & $<0.001$ & 0.01 & 0.004 & 0.9 & 0.5 & $<0.001$ & $<0.001$ & $<0.001$ & $<0.001$ & 0.02 & 0.003 & $<0.001$ & $<0.001$ & 0.8 & 0.2 & 0.05 \\
\hline Treatment & 0.003 & 0.001 & 0.007 & 0.005 & 0.8 & 0.6 & 0.5 & 0.2 & 0.1 & 0.7 & 0.06 & 0.05 & 0.01 & 0.4 & 0.01 & 0.01 & 0.002 & 0.5 & 0.01 & 0.3 \\
\hline Site $\times$ Harvest date & 0.2 & 0.3 & $<0.001$ & 0.09 & $<0.001$ & - & - & - & - & - & - & - & - & - & - & - & - & - & - & - \\
\hline Site $\times$ Treatment & 0.001 & $<0.001$ & 0.7 & 0.03 & 0.01 & 0.6 & 0.2 & 0.002 & 0.06 & 0.4 & 0.06 & 0.07 & 0.3 & 0.5 & 0.1 & 0.006 & 0.005 & 0.2 & 0.1 & 0.001 \\
\hline Harvest date $\times$ Treatment & 0.6 & 0.6 & 0.6 & 0.7 & 0.02 & 1.0 & 0.9 & 0.9 & 0.2 & 0.6 & 0.3 & 0.5 & 0.8 & 0.7 & 0.3 & 0.2 & 0.2 & 0.9 & 0.6 & 1.0 \\
\hline
\end{tabular}

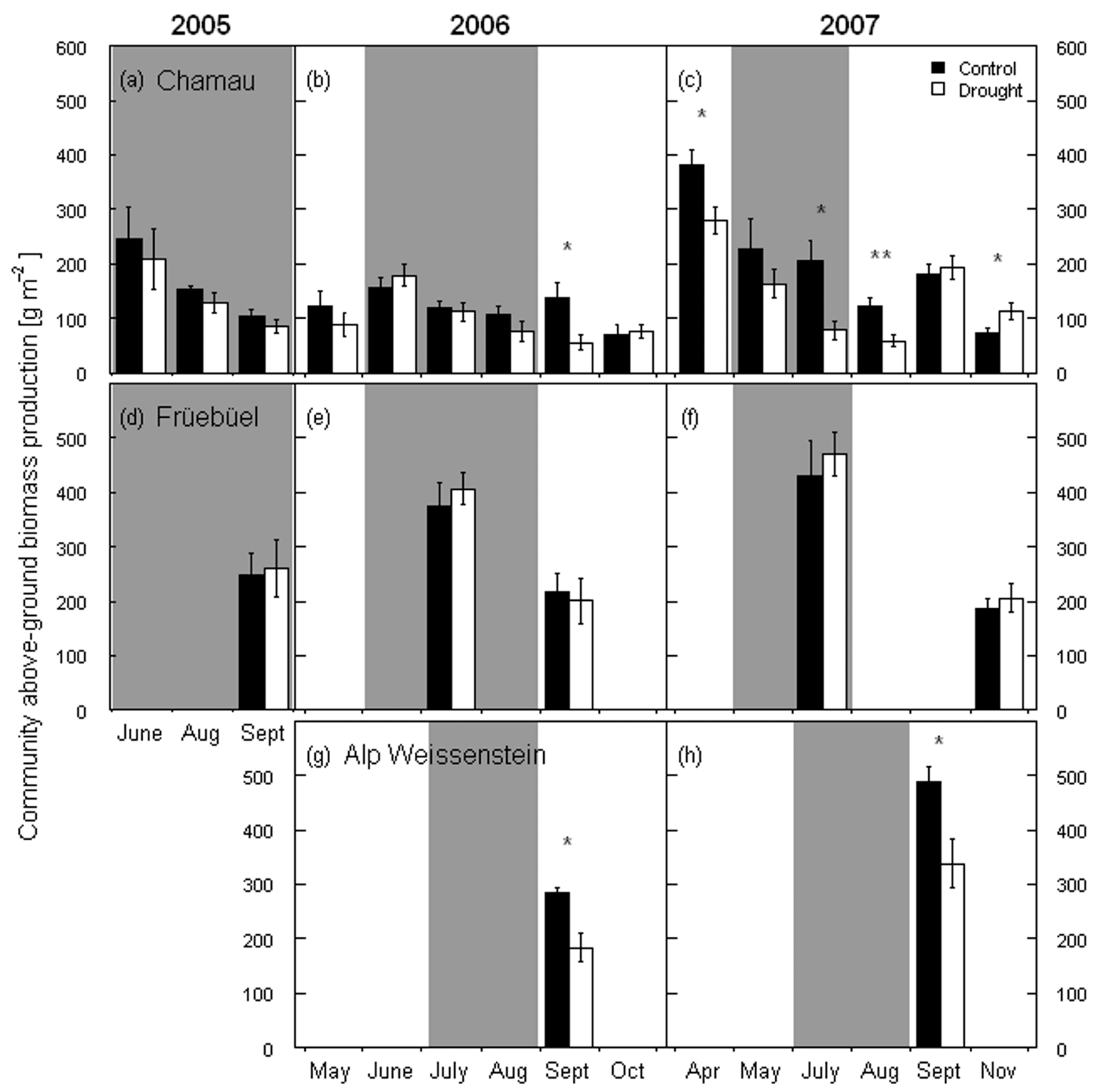

Fig. 3. Effect of summer drought on community above-ground biomass production (i.e. dead and alive plant material) at Chamau (excluding $R$. obtusifolius biomass; a-c), Früebüel (d-f) and Alp Weissenstein ( $\mathbf{g}-\mathbf{h})$ during the experiment. Bars represent biomass production per harvest (i.e. biomass regrown between cutting dates). Means and standard errors are given $(n=5-7)$. Periods of drought treatment are shaded in grey. ${ }^{*} 0.05 \geq P>0.01,{ }^{* *} 0.01 \geq P>0.001$. 


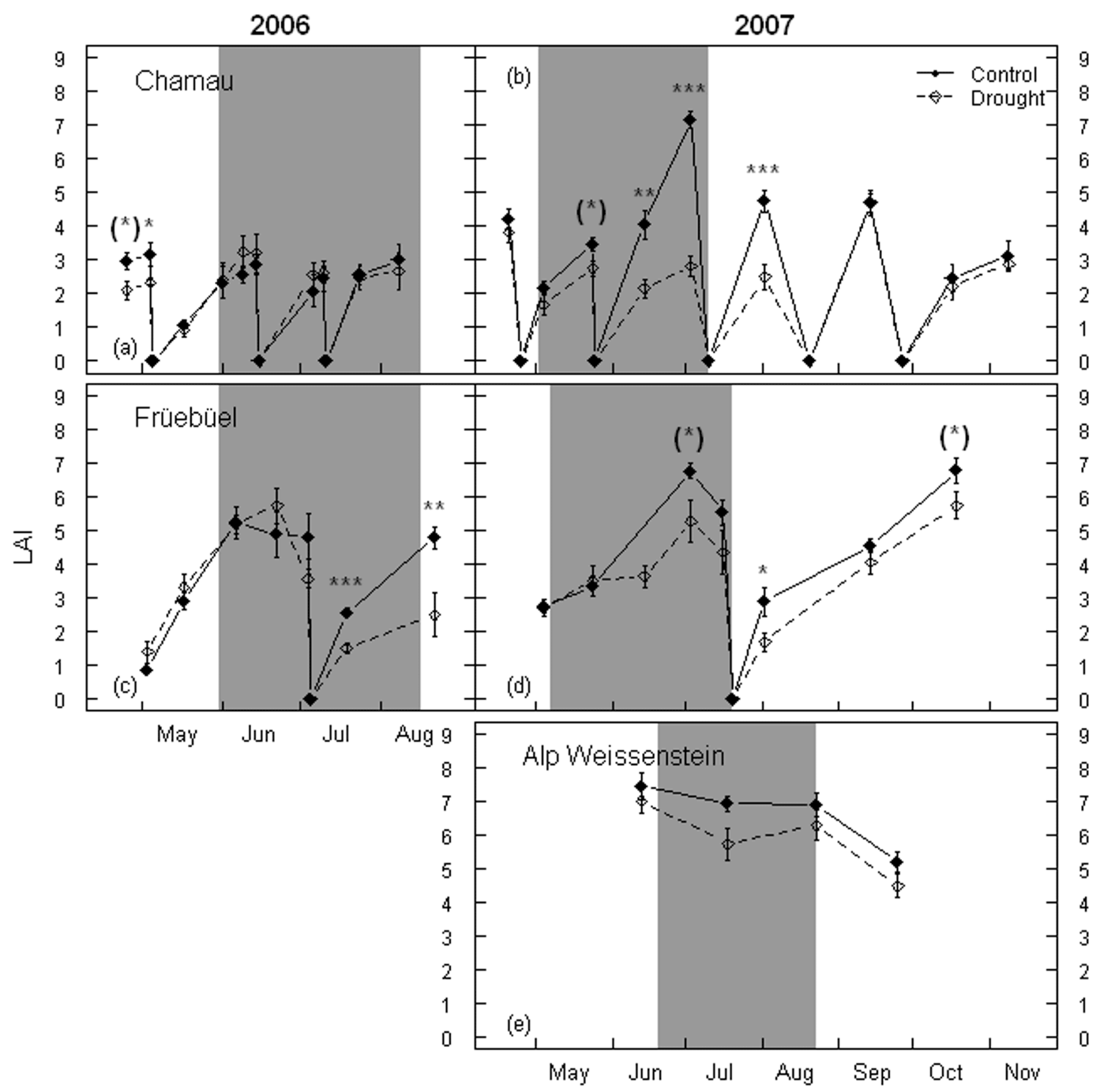

Fig. 4. Effect of summer drought on community leaf area index (LAI) at Chamau (a, b), Früebüel (c, d) and Alp Weissenstein (e) during the experiment. Means and standard errors are given $(n=3-7)$. Periods of drought treatment are shaded in grey. $(*) 0.1 \geq P>0.05$, * $0.05 \geq P>0.01,{ }^{* *} 0.01 \geq P>0.001,{ }^{* * *} P \leq 0.001$.

both years $(P<0.001)$ although there was no such effect on community above-ground biomass. At Alp Weissenstein, drought reduced LAI values $(P=0.02)$, but despite the large decrease in biomass under drought conditions this trend was not significant at the different measurement dates. No relationship of LAI before the cut with harvested community above-ground biomass was found at any of the three sites ( $R^{2} \leq 0.1, P>0.2$ but $P<0.001$ for Chamau).

Vegetation height (data not shown) developed similar to LAI but was not as strongly affected by the drought treatment as LAI (except for Alp Weissenstein where vegetation height was significantly reduced by drought). Vegetation height before the cuts was not related to community aboveground biomass at Chamau and Alp Weissenstein, in contrast to Früebüiel $\left(R^{2}=0.4, P<0.001\right)$.

\subsection{Root biomass}

Root biomass productivity differed significantly among sites $(P=0.01)$, with productivities being almost twice as high at Alp Weissenstein compared to Früebüel and Chamau (Fig. 5). However, below-ground productivity was not affected by the drought treatment $(P=0.9)$. In addition, the site $\times$ treatment interaction term was not significant $(P=0.9)$, indicating that the response of below-ground productivity to drought was similar across all three sites.

\subsection{Carbon isotope and nitrogen concentration measurements}

Bulk above-ground carbon isotope ratios $\left(\delta^{13} \mathrm{C}\right)$ ranged between $-31.3 \%$ and $-26.7 \%$ for the grassland vegetation (Fig. 6), with significant differences among sites $(P<0.001)$. 


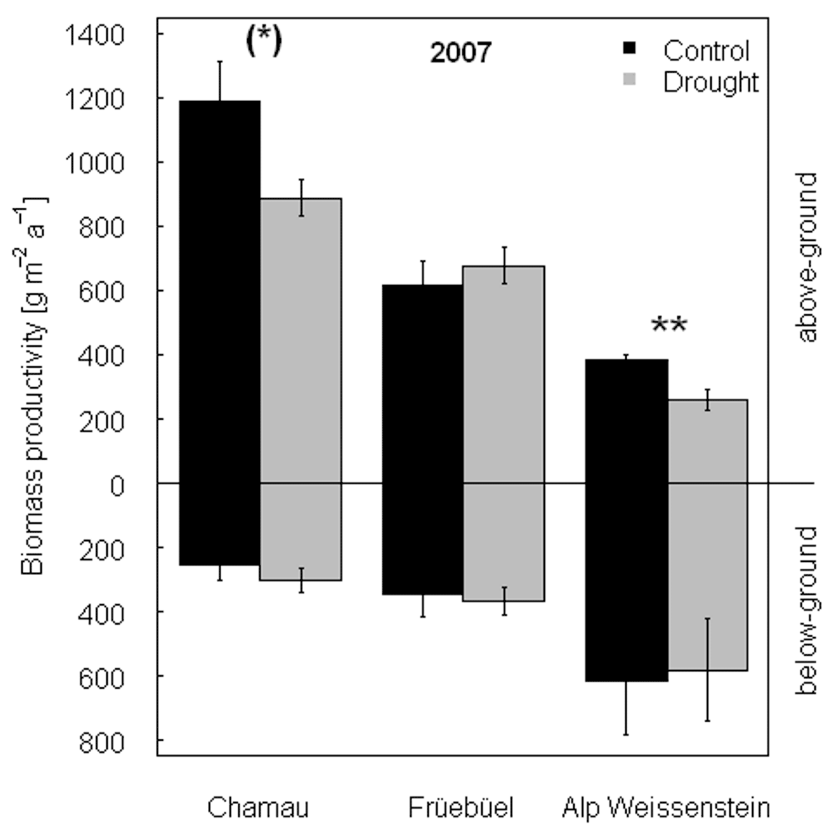

Fig. 5. Effect of summer drought on annual community above(dead and alive plant material) and below-ground biomass productivity at the three sites in 2007. Below-ground biomass was estimated using ingrowth cores. Means and standard errors are given ( $n=3-6$ ). $\left(^{*}\right) 0.1 \geq P>0.05,{ }^{* *} 0.01 \geq P>0.001$. No significant treatment effects on the below-ground biomass productivity were found.

$\delta^{13} \mathrm{C}$ values were highest for Alp Weissenstein and varied over the course of the growing season $(P<0.001)$. In addition, we found significant effects of the drought treatment on $\delta^{13} \mathrm{C}$ at all sites $(P<0.001)$. While drought increased $\delta^{13} \mathrm{C}$ in 2005 and 2007, there was only a delayed response in 2006 at Chamau (date $\times$ treatment interaction: $P<0.001$; Fig. 6ac). This was controlled by the drought response of grasses that contributed most to community biomass. Legumes on the other hand did not react to drought in 2005 and 2007 but instead significantly decreased their $\delta^{13} \mathrm{C}$ values in 2006 (data not shown). At Früebüel, the drought response of vegetation $\delta^{13} \mathrm{C}$ varied throughout the experiment but a nonsignificant harvest date $\times$ treatment interaction indicated no change in the direction of the drought effect (Fig. 6d-e). Grasses were the only functional group displaying an overall positive drought response but forbs also showed slightly increasing $\delta^{13} \mathrm{C}$ values in response to drought in 2007. The drought response of vegetation $\delta^{13} \mathrm{C}$ at Alp Weissenstein was mainly driven by a very strong positive drought effect in the first year (significant date and date $\times$ treatment interaction effects; Fig. 6g-h), dominated by grasses that showed highest increases in $\delta^{13} \mathrm{C}$ in response to drought as well as by the positive drought effect on $\delta^{13} \mathrm{C}$ of forbs in 2006. Interestingly, $\delta^{13} \mathrm{C}$ values of legumes were not significantly affected by drought, although legume biomass had been reduced significantly.
On the single species level, no clear patterns could be detected. Grass species showed clear drought responses but no species differed strikingly from the others. The only outstanding drought response was observed in R. obtusifolius at Chamau (excluded from all analyses, for detailed results see Gilgen et al., 2010).

Community nitrogen concentrations varied between $1.1 \%$ and $4.9 \%$, with highly significant differences among sites and harvest dates $(P<0.001$ each $)$. The drought treatment increased overall $\mathrm{N}$ concentrations in above-ground biomass significantly by around $0.15 \%(P=0.003)$. However, analysing the three years separately revealed that the drought effect was only significant in 2006. At Chamau, drought significantly increased $\mathrm{N}$ concentrations in aboveground biomass $(P<0.001)$. Independent of the treatment, $\mathrm{N}$ concentrations increased from around $2.5 \%$ in 2005 to more than $3.5 \%$ in autumn 2007. At Früebüel, no effect of drought on $\mathrm{N}$ concentrations was detected. At Alp Weissenstein, drought decreased average $\mathrm{N}$ concentrations at Alp Weissenstein, but this effect was only significant in the first year ( $P=0.001)$, not in the second year $(P=0.3)$ of the drought treatment.

\section{Discussion}

\subsection{Above-ground productivity and N supply}

Drought typically reduces above-ground biomass productivity in grasslands (Hopkins, 1978; Bollinger et al., 1991; Kahmen et al., 2005). In contrast to these findings and rather unexpected, no consistent decrease in community aboveground biomass under drought was observed in our experiment for all sites in all years. One might suspect that especially at Früebüel the plants were not really water stressed. However, measurements of pre-dawn leaf water potential, assimilation rate and stomatal conductance show that plants of all three plant functional types (grasses, herbs, legumes) were negatively affected by the reduced precipitation input (Signarbieux and Feller, 2008; Signarbieux, 2009). As environmental and management characteristics differed considerably among the three sites (i.e. site explained most of the differences in community above-ground biomass productivity) and with time (i.e. significant effect of the harvest date), the sites seemed to react rather site- and year-specific. However, there was a strong relationship of average annual community above-ground biomass response with annual precipitation. Sites with lower annual precipitation thus seem to be more vulnerable to summer drought than sites with higher annual precipitation. Moreover, if annual precipitation is very high (above 1500-2000 $\mathrm{mm}$ ), decreased precipitation input can even generate a beneficial effect on annual aboveground biomass productivity. The partial pressure of oxygen in wet soils is reduced due to decreased oxygen diffusion from the atmosphere and thus less oxygen is available for 


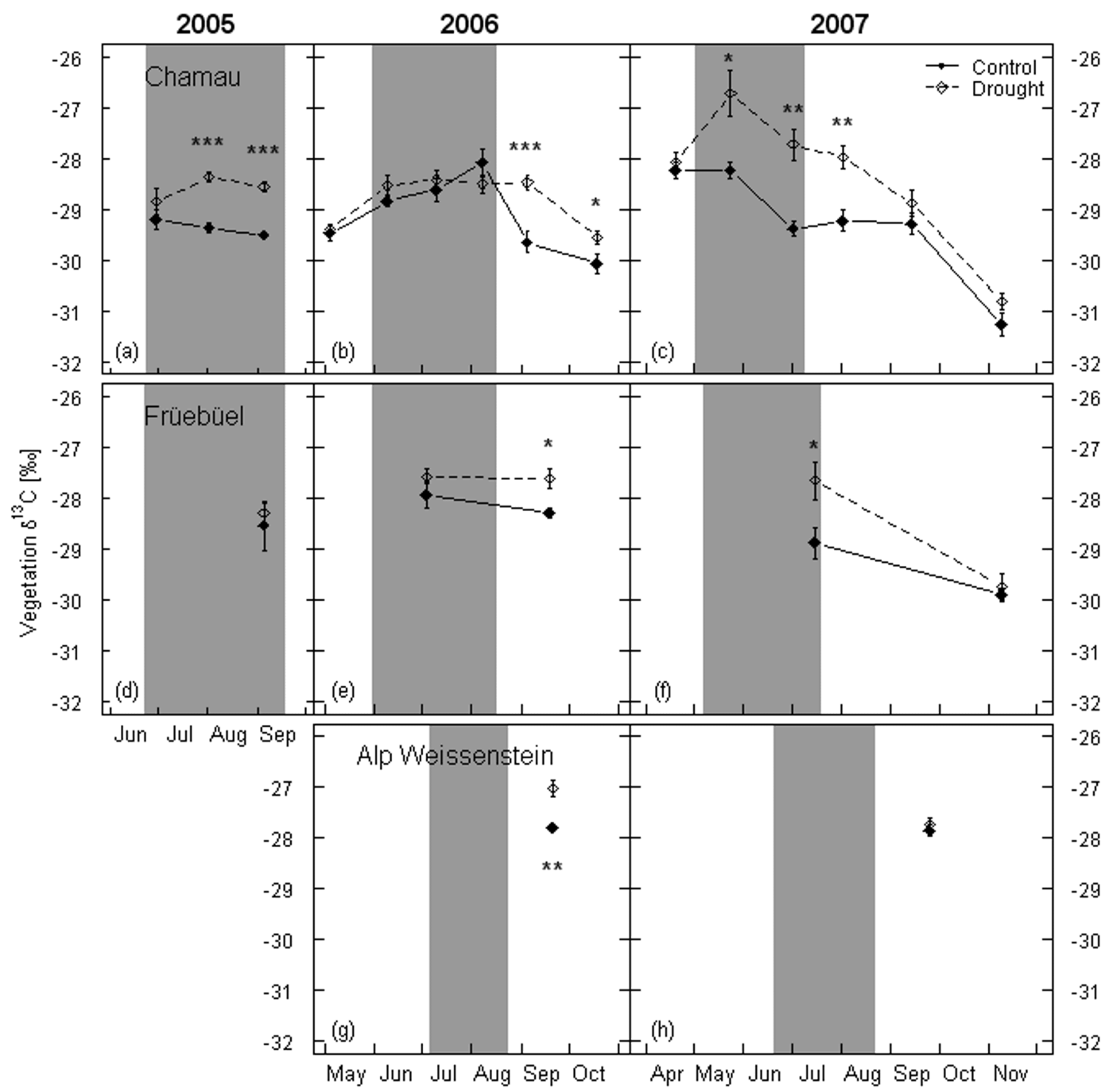

Fig. 6. Effect of summer drought on $\delta^{13} \mathrm{C}$ of vegetation (alive plant parts only) at Chamau (excluding Rumex obtusifolius; a-c), Früebüel (d-f) and Alp Weissenstein (g-h) during the experiment. Means and standard errors are given $(n=5-7)$. Periods of drought treatment are shaded in grey. ${ }^{*} 0.05 \geq P>0.01,{ }^{* *} 0.01 \geq P>0.001,{ }^{* * *} P \leq 0.001$.

root respiration. Also the availability of nutrients can be limited in wet conditions due to changes in redox potentials and microbial activities which will also negatively affect plant performance (Nilsen and Orcutt, 1996). The lacking relationship of average annual community above-ground biomass response with the fraction of annual precipitation excluded by the shelters or with growing degree days clearly indicates that long-term annual precipitation rather than temperature controlled the drought response of these grasslands. A dependence of biomass production on soil moisture at drier sites but not at wetter sites was found for shrublands (Penuelas et al., 2007).

Grasses contributed most to community biomass (generally more than $50 \%$, except for Chamau in 2006), thus reflecting the response of the community well or rather shaping the response of the community. Also Grime et al. (2000) had found that perennial grasses were particularly vulnerable to climate change in a limestone grassland. This is supported by findings from a companion study showing that drought had a strong negative impact on the physiological performance of grasses (especially at Chamau, Signarbieux and Feller, 2008). On the other hand, we found only slight effects of drought on forbs or legumes (except for R. obtusifolius at Chamau in 2006, Gilgen et al., 2010). Although Trifolium repens, the most abundant legume species at our sites, has been shown to be drought sensitive (Foulds, 1978; Stevenson and Laidlaw, 1985), in our study, the fraction of $T$. repens of community biomass was not significantly affected by drought (except at Alp Weissenstein in 2006). Furthermore, the amount of dead biomass was slightly increased under drought, with the strongest effect again at the driest site, Alp Weissenstein, in 2006. This increase in 
dead biomass in drought plots was probably caused by earlier senescence as has been reported in other studies as well (Volaire, 2002; Monti et al., 2007).

Although other factors than water can also limit plant productivity, such as N (Harpole et al., 2007), we can fairly assume that the three grasslands studied here were not $\mathrm{N}$ limited throughout the experiment. This was shown in a longterm biodiversity experiment in Germany where biomass productivity was not affected by the lack of fertilisation after six years (Marquard et al., 2009). Prior to our experiment, the plots at the two lower sites were regularly fertilised with manure, according to Swiss regulations. At Chamau, this high fertilisation was even shown to control the $\mathrm{C}$ cycle more than climate (Zeeman et al., 2009). Increasing $\mathrm{N}$ concentrations in above-ground biomass in drought plots at Chamau and no change in $\mathrm{N}$ concentrations at Früebüel indicate an appropriate $\mathrm{N}$ supply. Even at the alpine site where drought decreased $\mathrm{N}$ concentrations in 2006, we can still assume there was no $\mathrm{N}$ limitation since biomass productivity was higher in the second year than in the first year of the experiment and $\mathrm{N}$ concentrations in above-ground biomass were unaffected by the treatment in the second year.

\subsection{Below-ground productivity}

Below-ground productivity can also react to drought: plants are able to sense the water available in soils and when the soil dries out, they produce abscisic acid (ABA) which was shown to maintain or increase root growth while shoot growth is inhibited (Saab et al., 1990; Davies and Zhang, 1991; Tardieu et al., 1992). Indeed, increased root growth under drought was often found in other studies (Jupp and Newman, 1987; Field et al., 1992; Kalapos et al., 1996; van den Boogaard et al., 1996; Kahmen et al., 2005). However, in our study, no change in below-ground biomass productivity was observed at any of the three sites. One reason could be that roots of different grass species reacted differently to drought (Molyneux and Davies, 1983; Bessler et al., 2009) and could thus compensate each other to hold community root biomass constant. Another explanation could be timing. Since our ingrowth cores remained in the field for a whole season or longer and not only during the drought treatment, the untreated conditions during most of the season might have dampened any drought effect. Still, on an annual basis, constant below-ground compared to decreasing aboveground productivity resulted in a higher root/shoot ratio of total plant biomass, thus indicating an increased allocation of resources to root growth.

\subsection{Carbon isotope measurements}

According to theory, $\delta^{13} \mathrm{C}$ of plants can be used as an estimate for water use efficiency (integrated WUE) because the

${ }^{13} \mathrm{C}$ signature depends on the ratio of intercellular to ambient $\mathrm{CO}_{2}$ concentrations $\left(\mathrm{c}_{i} / \mathrm{c}_{a}\right.$, Farquhar et al., 1982) and an increase in $\delta^{13} \mathrm{C}$ is thus coupled to a decrease in $\mathrm{c}_{i} / \mathrm{c}_{a}$, which can either be caused by higher photosynthetic fixation or decreasing stomatal conductance (Farquhar et al., 1989). Although this simplified view has recently been discussed rather critically (Seibt et al., 2008), our data still met the predictions made based on those earlier assumptions, i.e. an increase in $\delta^{13} \mathrm{C}$ under drier condition due to decreased stomatal conductance (Signarbieux and Feller, 2009). Vegetation $\delta^{13} \mathrm{C}$ was more positive in drought plots than in control plots at all sites in all years, although other physiological processes than just photosynthesis, e.g. cell elongation and protein synthesis, might affect growth even more strongly than photosynthesis (Lambers et al., 1998). Nevertheless, vegetation $\delta^{13} \mathrm{C}$ was mainly controlled by grass $\delta^{13} \mathrm{C}$ values that were also higher in drought plots than in control plots while forb and legume $\delta^{13} \mathrm{C}$ values were unaffected by drought indicating no change in WUE efficiency in these two plant functional types.

\subsection{Perspectives}

Extrapolating results of the present study to the future might be difficult, since not only the amount of summer precipitation is changing under climate change but also of winter precipitation as well as timing and variability of rainfall, both important for grassland productivity (Nippert et al., 2006; Heisler-White et al., 2008). Future winters are predicted to be wetter than today in Central Europe (Frei et al., 2006). Higher winter precipitation will therefore probably recharge water reservoirs regularly, thereby buffering any summer drought effects. In addition, it has been shown that winter precipitation had no effect on biomass productivity, which was rather controlled by summer precipitation of the previous and the current year (Morecroft et al., 2004). This indicates that even if community above-ground biomass productivity recovered quickly after the removal of the rain shelters in our experiment, a long-term effect could still have been preserved.

Under future climate change drier summers will also be accompanied by higher atmospheric $\mathrm{CO}_{2}$ concentrations. These have been shown to lead to water savings due to a reduced stomatal opening (Campbell et al., 1997; Volk et al., 2000). However, the relatively strong reductions of biomass productivity at Alp Weissenstein and at Chamau in 2007 will probably not be offset by the typically small water saving effects under increasing $\mathrm{CO}_{2}$ as observed in Swiss forest (Leuzinger et al., 2005) and grassland sites (Volk et al., 2000).

In conclusion, results from this study indicate that there is no uniform grassland response to drought in Switzerland. Different grassland types as well as different plant functional types differed in their response to drought. However, the drought response scaled with total annual precipitation, thus sites with high annual precipitation seem to be better buffered against disturbance by summer drought than sites with low 
annual precipitation. If this is also true in other parts of Europe remains to be tested, but it already now emphasises the strong needs for adapted management strategies in the drier parts of Switzerland.

Acknowledgements. Matthias J. Zeeman, Rebecca Hiller (both ETH Zurich) and Pavel Michna (University of Bern) are acknowledged for kindly providing precipitation data, Peter Plüss for technical support and Patrick Flütsch (both ETH Zurich) for metal shop work. Hans Leuenberger and Hans-Ruedi Wettstein and all employees of the three ETH research stations are acknowledged for their support and hospitality. We thank the Grassland Isolab for isotope analyses, Karin Beer, David Brändli, Anni and Peter Dürsteler, Jenny Gassmann, Clea Henzen, Barbara Meier, Ana Rangl, Carolin Ries and Mirjam Spalinger for sample preparation. This study was funded by the NCCR Climate and a grant of the Walter Hochstrasser-Stiftung to AKG.

Edited by: G. Wohlfahrt

\section{References}

Arp, W. J., Van Mierlo, J. E. M., Berendse, F., and Snijders, W.: Interactions between elevated $\mathrm{CO}_{2}$ concentration, nitrogen and water: effects on growth and water use of six perennial plant species, Plant Cell Environ., 21, 1-11, 1998.

Bessler, H., Temperton, V. M., Roscher, C., Buchmann, N., Schmid, B., Schulze, E. D., Weisser, W. W., and Engels, C.: Aboveground overyielding in experimental grassland mixtures is associated with reduced biomass partitioning to below-ground organs, Ecology, 90, 1520-1530, 2009.

Bollinger, E. K., Harper, S. J., and Barrett, G. W.: Effects of seasonal drought on old field plant communities, Am. Midl. Nat., 125, 114-125, 1991.

Brooks, P. D., Geilmann, H., Werner, R. A., and Brand, W. A.: Improved precision of coupled $\delta^{13} \mathrm{C}$ and $\delta^{15} \mathrm{~N}$ measurements from single samples using an elemental analyser/isotope ratio mass spectrometer combination with a post-column 6-port valve and selective $\mathrm{CO}_{2}$ trapping; improved halide robustness of the combustion reactor using $\mathrm{CeO}_{2}$, Rapid Commun. Mass Sp., 17, 1924-1926, 2003.

Campbell, B. D., Smith, D. M. S., and McKeon, G. M.: Elevated $\mathrm{CO}_{2}$ and water supply interactions in grasslands: A pastures and rangelands management perspective, Global Change Biol., 3, 177-187, 1997.

Christensen, J. H., Hewitson, B., Busuioc, A., Chen, A., Gao, X., Held, I., Jones, R., Kolli, R. K., Kwon, W.-T., Laprise, R., Magaña Rueda, V., Mearns, L., Menéndez, C. G., Räisänen, J., Rinke, A., Sarr, A., and Whetto, P.: Regional Climate Projections, in: Climate Change 2007: the Physical Science Basis. Contribution of Working Group I to the Fourth Assessment Report of the Intergovernmental Panel on Climate Change, edited by: Solomon, S., Qin, D., Manning, M., Chen, Z., Marquis, M., Averyt, K. B., Tignor, M., and Miller, H. L., Cambridge University Press, Cambridge, UK, 847-940, 2007.

Davies, W. J. and Zhang, J. H.: Root signals and the regulation of growth and development of plants in drying soil, Annu. Rev. Plant Phys., 42, 55-76, 1991.
English, N. B., Weltzin, J. F., Fravolini, A., Thomas, L., and Williams, D. G.: The influence of soil texture and vegetation on soil moisture under rainout shelters in a semi-desert grassland, J. Arid. Environ., 63, 324-343, 2005.

Farquhar, G. D., Oleary, M. H., and Berry, J. A.: On the relationship between carbon isotope discrimination and the inter-cellular carbon-dioxide concentration in leaves, Aust. J. Plant Physiol., 9, 121-137, 1982.

Farquhar, G. D., Ehleringer, J. R., and Hubick, K. T.: Carbon isotope discrimination and photosynthesis, Annu. Rev. Plant Phys., 40, 503-537, 1989.

Fay, P. A., Carlisle, J. D., Danner, B. T., Lett, M. S., McCarron, J. K., Stewart, C., Knapp, A. K., Blair, J. M., and Collins, S. L.: Altered rainfall patterns, gas exchange, and growth in grasses and forbs, Int. J. Plant Sci., 163, 549-557, 2002.

Fay, P. A., Carlisle, J. D., Knapp, A. K., Blair, J. M. and Collins, S. L.: Productivity responses to altered rainfall patterns in a $\mathrm{C}_{4}-$ dominated grassland, Oecologia, 137, 245-251, 2003.

Field, C. B., Chapin, F. S., Matson, P. A. and Mooney, H. A.: Responses of terrestrial ecosystems to the changing atmosphere - A resource-based approach, Annu. Rev. Ecol. Syst., 23, 201-235, 1992.

Foulds, W.: Response to soil moisture supply in three leguminous species. 1. Growth, reproduction and mortality, New Phytol., 80, 535-545, 1978.

Frei, C., Schöll, R., Fukutome, S., Schmidli, J., and Vidale, P. L.: Future change of precipitation extremes in Europe: Intercomparison of scenarios from regional climate models, J. Geophys. Res.-Atmos., 111, D06105, doi:10.1029/2005JD005965, 2006.

Gibbens, R. P. and Beck, R. F.: Changes in grass basal area and forb densities over a 64-year period on grassland types of the Jornada Experimental Range, J. Range Manage., 41, 186-192, 1988.

Gilgen, A. K., Signarbieux, C., Feller, U., and Buchmann, N.: Competitive advantage of Rumex obtusifolius L. might increase in intensively managed temperate grasslands under drier climate, Agr. Ecosyst. Environ., 135, 15-23, 2010.

Greco, S. A. and Cavagnaro, J. B.: Effects of drought in biomass production and allocation in three varieties of Trichloris crinita P. (Poaceae) a forage grass from the arid Monte region of Argentina, Plant Ecol., 164, 125-135, 2003.

Grime, J. P., Brown, V. K., Thompson, K., Masters, G. J., Hillier, S. H., Clarke, I. P., Askew, A. P., Corker, D., and Kielty, J. P.: The response of two contrasting limestone grasslands to simulated climate change, Science, 289, 762-765, 2000.

Harpole, W. S., Potts, D. L., and Suding, K. N.: Ecosystem responses to water and nitrogen amendment in a California grassland, Global Change Biol., 13, 2341-2348, 2007.

Heisler-White, J. L., Knapp, A. K., and Kelly, E. F.: Increasing precipitation event size increases aboveground net primary productivity in a semi-arid grassland, Oecologia, 158, 129-140, 2008.

Hopkins, B.: The effects of the 1976 drought on chalk grassland in Sussex, England, Biol. Conserv., 14, 1-12, 1978.

Jupp, A. P. and Newman, E. I.: Morphological and anatomical effects of severe drought on the roots of Lolium perenne L., New Phytol., 105, 393-402, 1987.

Kahmen, A., Perner, J., and Buchmann, N.: Diversity-dependent productivity in semi-natural grasslands following climate perturbations, Funct. Ecol., 19, 594-601, 2005. 
Kalapos, T., van den Boogaard, R., and Lambers, H.: Effect of soil drying on growth, biomass allocation and leaf gas exchange of two annual grass species, Plant Soil, 185, 137-149, 1996.

Karsten, H. D. and MacAdam, J. W.: Effect of drought on growth, carbohydrates, and soil water use by perennial ryegrass, tall fescue, and white clover, Crop Sci., 41, 156-166, 2001.

Keller, P.: Vegetationskundliche Untersuchungen und Ertrag der Grünlandflächen im Gebiet der ETH-Forschungsstation Alp Weissenstein GR, Diploma Thesis, University of Zurich, Switzerland, 119 pp., 2006.

Knapp, A. K., Briggs, J. M. and Koelliker, J. K.: Frequency and extent of water limitation to primary production in a mesic temperate grassland, Ecosystems, 4, 19-28, 2001.

Knapp, A. K. and Smith, M. D.: Variation among biomes in temporal dynamics of aboveground primary production, Science, 291, 481-484, 2001.

Köchy, M. and Wilson, S. D.: Semiarid grassland responses to short-term variation in water availability, Plant Ecol., 174, 197203, 2004

Lambers, H., Chapin, F. S., and Pons, T. L.: Plant physiological ecology, Springer, New York, NY, USA, 1998.

Leuzinger, S., Zotz, G., Asshoff, R., and Körner, C.: Responses of deciduous forest trees to severe drought in Central Europe, Tree Physiol., 25, 641-650, 2005.

Marquard, E., Weigelt, A., Temperton, V. M., Roscher, C., Schumacher, J., Buchmann, N., Fischer, M., Weisser, W. W., and Schmid, B.: Plant species richness and functional composition drive overyielding in a 6-year grassland experiment, Ecology, in press, 2009.

Mikkelsen, T. N., Beier, C., Jonasson, S., Holmstrup, M., Schmidt, I. K., Ambus, P., Pilegaard, K., Michelsen, A., Albert, K., Andresen, L. C., Arndal, M. F., Bruun, N., Christensen, S., Danbaek, S., Gundersen, P., Jorgensen, P., Linden, L. G., Kongstad, J., Maraldo, K., Prieme, A., Riis-Nielsen, T., Ro-Poulsen, H., Stevnbak, K., Selsted, M. B., Sorensen, P., Larsen, K. S., Carter, M. S., Ibrom, A., Martinussen, T., Miglietta, F., and Sverdrup, H.: Experimental design of multifactor climate change experiments with elevated $\mathrm{CO}_{2}$, warming and drought: the CLIMAITE project, Funct. Ecol., 22, 185-195, 2008.

Molyneux, D. E. and Davies, W. J.: Rooting pattern and water relations of three pasture grasses growing in drying soil, Oecologia, 58, 220-224, 1983.

Monti, A., Barbanti, L., and Venturi, G.: Photosynthesis on individual leaves of sugar beet (Beta vulgaris) during the ontogeny at variable water regimes, Ann. Appl. Biol., 151, 155-165, 2007.

Morecroft, M. D., Masters, G. J., Brown, V. K., Clarke, I. P., Taylor, M. E., and Whitehouse, A. T.: Changing precipitation patterns alter plant community dynamics and succession in an ex-arable grassland, Funct. Ecol., 18, 648-655, 2004.

Nilsen, E. T. and Orcutt, D. M.: The physiology of plants under stress, John Wiley \& Sons, Inc., New York, USA, 1996.

Nippert, J. B., Knapp, A. K., and Briggs, J. M.: Intra-annual rainfall variability and grassland productivity: can the past predict the future?, Plant Ecol., 184, 65-74, 2006.

Nippert, J. B., Fay, P. A., Carlisle, J. D., Knapp, A. K., and Smith, M. D.: Ecophysiological responses of two dominant grasses to altered temperature and precipitation regimes, Acta Oecol., 35, 400-408, 2009.
Paruelo, J. M., Lauenroth, W. K., Burke, I. C. and Sala, O. E.: Grassland precipitation-use efficiency varies across a resource gradient, Ecosystems, 2, 64-68, 1999.

Penuelas, J., Prieto, P., Beier, C., Cesaraccio, C., de Angelis, P., de Dato, G., Emmett, B. A., Estiarte, M., Garadnai, J., Gorissen, A., Lang, E. K., Kroel-Dulay, G., Llorens, L., Pellizzaro, G., RiisNielsen, T., Schmidt, I. K., Sirca, C., Sowerby, A., Spano, D., and Tietema, A.: Response of plant species richness and primary productivity in shrublands along a north-south gradient in Europe to seven years of experimental warming and drought: reductions in primary productivity in the heat and drought year of 2003, Global Change Biol., 13, 2563-2581, 2007.

R Development Core Team: R: A language and environment for statistical computing, 2.5.0 ed., R Foundation for Statistical Computing, Vienna, Austria, 2007.

Roth, K.: Bodenkartierung und GIS-basierte Kohlenstoffinventur von Graslandböden: Untersuchungen an den ETHForschungsstationen Chamau und Früebüel (ZG, Schweiz), Diploma Thesis, University of Zurich, Switzerland, 132 pp., 2006.

Saab, I. N., Sharp, R. E., Pritchard, J., and Voetberg, G. S.: Increased endogenous abscisic acid maintains primary root growth and inhibits shoot growth in maize seedlings at low water potentials, Plant Physiol., 93, 1329-1336, 1990.

Sautier, S.: Zusammensetzung und Produktivität der Vegetation im Gebiet der ETHZ-Forschungsstation Früebüel (ZG), Diploma Thesis, University of Zurich, Switzerland, 123 pp., 2007.

Schärer, M.: Kurzbericht der Fallstudie Alp Weissenstein. Nährstoffanalysen in Alpweiden Sommer 2002, Term Paper, ETH Zurich, Switzerland, 44 pp., 2003.

Schwinning, S., Starr, B. I. and Ehleringer, J. R.: Summer and winter drought in a cold desert ecosystem (Colorado Plateau) part II: effects on plant carbon assimilation and growth, J. Arid. Environ., 61, 61-78, 2005.

Seibt, U., Rajabi, A., Griffiths, H., and Berry, J. A.: Carbon isotopes and water use efficiency: sense and sensitivity, Oecologia, 155, 441-454, 2008.

Sherry, R. A., Weng, E., Arnone III, J. A., Johnson, D. W., Schimel, D., Verburg, P. S., Wallace, L. L., and Luo, Y. Q.: Lagged effects of experimental warming and doubled precipitation on annual and seasonal aboveground biomass production in a tallgrass prairie, Global Change Biol., 14, 2923-2936, 2008.

Signarbieux, C. and Feller, U.: Effects of an extended drought period on grasslands at various altitudes in Switzerland: A field study, in: Photosynthesis. Energy from the Sun. 14th International Congress on Photosynthesis, edited by: Allen, J. F., Gantt, E., Golbeck, J. H., and Osmond, B., Springer, Dordrecht, Netherlands, 1371-1374, 2008.

Signarbieux, C.: Grasslands in a changing climate in Switzerland: photosynthetic performance and water relations of selected species under artificial drought, $\mathrm{PhD}$ Thesis, University of Bern, Switzerland, 127 pp., 2009.

Signarbieux, C. and Feller, U.: Effects of an extended drought period on physiological properties of grasslands species in Switzerland, in preparation, 2009.

Stampfli, A. and Zeiter, M.: Plant regeneration directs changes in grassland composition after extreme drought: a 13-year study in southern Switzerland, J. Ecol., 92, 568-576, 2004. 
Sternberg, M., Brown, V. K., Masters, G. J., and Clarke, I. P.: Plant community dynamics in a calcareous grassland under climate change manipulations, Plant Ecol., 143, 29-37, 1999.

Stevenson, C. A. and Laidlaw, A. S.: The effect of moisture stress on stolon and adventitious root development in white clover (Trifolium repens L.), Plant Soil, 85, 249-257, 1985.

Tardieu, F., Zhang, J., Katerji, N., Bethenod, O., Palmer, S., and Davies, W. J.: Xylem ABA controls the stomatal conductance of field-grown maize subjected to soil compaction or soil drying, Plant Cell Environ., 15, 193-197, 1992.

van den Boogaard, R., Veneklaas, E. J. and Lambers, H.: The association of biomass allocation with growth and water use efficiency of two Triticum aestivum cultivars, Aust. J. Plant Physiol., 23, 751-761, 1996.

Volaire, F.: Drought survival, summer dormancy and dehydrin accumulation in contrasting cultivars of Dactylis glomerata, Plant Physiol., 116, 42-51, 2002.

Volk, M., Niklaus, P. A., and Körner, C.: Soil moisture effects determine $\mathrm{CO}_{2}$ responses of grassland species, Oecologia, 125, 380$388,2000$.
Weaver, J. E., Stoddart, L. A., and Noll, W.: Response of the prairie to the great drought of 1934, Ecology, 16, 612-629, 1935.

Werner, R. A., Bruch, B. A. and Brand, W. A.: ConFlo III - An interface for high precision $\delta^{13} \mathrm{C}$ and $\delta^{15} \mathrm{~N}$ analysis with an extended dynamic range, Rapid Commun. Mass Sp., 13, 12371241, 1999.

Werner, R. A. and Brand, W. A.: Referencing strategies and techniques in stable isotope ratio analysis, Rapid Commun. Mass Sp., 15, 501-519, 2001.

Werner, R. A.: The online ${ }^{18} \mathrm{O} /{ }^{16} \mathrm{O}$ analysis: Development and application, Isot. Environ. Healt. S., 39, 85-104, 2003.

Zeeman, M. J.: Environmental processes affecting the carbon dioxide budget of grasslands along an elevational gradient in Switzerland, PhD Thesis, ETH Zurich, Switzerland, 219 pp., 2008.

Zeeman, M. J., Hiller, R., Gilgen, A. K., Michna, P., Plüss, P., Buchmann, N., and Eugster, W.: Management, not climate, controls net $\mathrm{CO}_{2}$ fluxes and carbon budgets of three grasslands along an elevational gradient in Switzerland, Agric. For. Meteorol., submitted, 2009. 